\title{
COMPARATIVE IMMUNOHISTOCHEMICAL AND BIOCHEMICAL ANALYSIS OF PANCREATIC POLYPEPTIDE-LIKE PEPTIDES WITH SPECIAL REFERENCE TO PRESENCE OF NEUROPEPTIDE Y IN CENTRAL AND PERIPHERAL NEURONS ${ }^{1}$
}

\author{
JAN M. LUNDBERG, ${ }^{* 2}$ LARS TERENIUS, $\ddagger$ TOMAS HÖKFELT,§ AND KAZUHIKO TATEMOTO \\ Departments of *Pharmacology, §Histology, and \| Biochemistry, Karolinska Institutet, Stockholm, and $\ddagger$ Department of \\ Pharmacology, University of Uppsala, Uppsala, Sweden
}

Received January 5, 1984; Accepted March 20, 1984

\begin{abstract}
Antisera raised against porcine neuropeptide Y (NPY) and peptide YY (PYY) were characterized with regard to immunohistochemical staining, cross-reactivity to several pancreatic polypeptide (PP)-related peptides, and radioimmunoassayable tissue levels in the rat and pig. The NPY antiserum (102B) reacted with nerves in many areas of both the central and peripheral nervous systems, but it did not stain endocrine cells of the pancreas or intestine. No evidence for any cross-reactivity of the NPY antiserum with related peptides of the PP family, such as avian PP, bovine PP, PYY, $\gamma$-MSH, FMRF-amide, or avian PP (31-36), was obtained. The NPY antiserum was N-terminally directed, and regional levels of NPY as seen by radioimmunoassay paralleled well the occurrence of NPY-immunoreactive structures seen in the immunohistochemical study. High pressure liquid chromatography analysis revealed that the NPY-immunoreactive material from cerebral cortex and vas deferens had elution profiles similar to those of standard porcine NPY. The PYY antiserum mainly stained endocrine cells in the pancreas and intestine as well as a small neuron system in the brainstem of the rat. Although this antiserum had a slight cross-reactivity to NPY in radioimmunoassay, the neuronal PYY staining was separate from that of NPY. High levels of PYY were found in the intestine, and levels above the threshold were also seen in the dorsal vagal complex of the rat. The other antisera investigated (raised against avian PP, bovine PP, $\gamma-\mathrm{MSH}$, and FMRF-amide) caused neuronal staining that was abolished by preabsorption with NPY. This was also seen even if no detectable cross-reactivity with NPY was found in radioimmunoassay. These latter antisera also stained endocrine cells in the pancreas and intestine with complex cross-reactivity relationships, suggesting the presence of intestinal PP-like peptides in addition to PYY and NPY.
\end{abstract}

Pancreatic polypeptide (PP) was originally isolated from bovine (Lin and Chance, 1974) and avian pancreas (Kimmel et al., 1975). Avian pancreatic polypeptide (APP) differs from bovine $\mathrm{PP}(\mathrm{BPP})$ in the amino acid sequence in as much as 21

\footnotetext{
${ }^{1}$ This study was supported by grants from the Swedish Medical Research Council (Grants 14X-6554, 04X-2887, 13X-1010, 04X-3766), the Swedish Tobacco Company, the Council for Tobacco ResearchU.S.A., Inc., Wibergs Stiftelse, Augusta och Petrus Hedlunds Stiftelse, Magnus Bergvalls Stiftelse, Karolinska Institutets Forskningsfonder, Svenska Läkarsällskapet, Astra Foundation, the National Institute of Neurological and Communicative Disorders and Stroke (Grant 0680), and the National Institute of Mental Health (Grant 02714). We thank Dr. R. Chance, Eli Lilly and Company (Indianapolis, IN), Dr. R. P. Elde, Department of Anatomy, University of Minnesota Medical School (Minneapolis, MN), and Professor R. Kimmel, VA Medical Center (Kansas City, MO) for the generous supply of peptides or antisera. For skillful technical assistance we are grateful to Mrs. I. Eriksson, Miss A. Hemsen, and Mrs. W. Hiort. For expert secretarial help we thank Mrs. Hilka Lindberg.

${ }^{2}$ To whom correspondence should be addressed, at Department of Pharmacology, Karolinska Institutet, Box 60400, S-104 01 Stockholm, Sweden.
}

of 36 positions. These peptides were demonstrated early with immunohistochemistry in a special type of endocrine cell of the Langerhans islets (Larsson et al., 1976). Subsequently, it was found that antiscra raised against APP, BPP, or the carboxyterminal hexapeptide of BPP also induced immunostaining of the central and peripheral nervous systems including some catecholaminergic nerves (Lorén et al., 1979; Lundberg et al., 1980; Hökfelt et al., 1981; Hunt et al, 1981; Olschowka et al., 1981; Jacobowitz and Olschowka, 1982; Taylor and Vaillant, 1983). However, we and others (Gu et al., 1983; J. R. Kimmel and P. Emson, personal communications) failed to measure immunoreactivity with different APP antisera by radioimmunoassay (RIA).

The isolation of peptide YY (PYY), another member of the $\mathrm{PP}$ family in intestinal extracts (the peptide $(\mathrm{P})$ with $\mathrm{NH}_{2}$ - and $\mathrm{COOH}$-terminal tyrosine (Y)) (Tatemoto, 1982a), raised the possibility that this was the neuronal peptide reacting with various $\mathrm{PP}$ antisera in the immunohistochemical analysis. However, this did not appear to be the case, since PYY was found to occur in endocrine cells, mainly in distal intestine (Lundberg et al., 1982c).

Recently, extracts of porcine brain (Tatemoto et al., 1982; Tatemoto, 1982b) were found to contain another peptide, neu- 
ropeptide $\mathrm{Y}(\mathrm{NPY}$, the neuronal $(\mathrm{N})$ peptide $(\mathrm{P})$ with $\mathrm{COOH}$ terminal tyrosine $(\mathrm{Y})$ ) with extensive structural similarities to the other PP-related peptides. NPY, PYY, APP, and BPP have in fact around 20 of 36 amino acids in identical positions, and many exchanges seem to be compensating; i.e., they occur between structurally similar amino acids. When antisera were subsequently raised to NPY, they were found to react essentially with the same nervous structures as previously recognized with APP or BPP antisera (Lundberg et al., 1982b; Gu et al., 1983; Hökfelt et al., 1983; Sundler et al., 1983; Everitt et al., 1984). Thus, catecholamine neurons in several species including humans contained NPY-immunoreactive (IR) material (Hökfelt et al., 1973; Lundberg et al., 1982b, c; Everitt et al., 1984). Evidence for the adrenergic nature of these nerves was their staining with antisera raised to tyrosine hydroxylase, dopamine $\beta$-hydroxylase, or phenylethanolamine- $N$-methyltransferase, which are markers for catecholaminergic neurons (see Hökfelt et al., 1973) and a loss of NPY immunoreactivity in many peripheral organs, including vas deferens and heart, induced by 6-hydroxydopamine (6-OHDA) pretreatment (Lundberg et al., 1982b). However, both in the central and peripheral nervous systems there seem to exist, in addition, extensive non-catecholaminergic NPY-IR systems. In the periphery this is indicated, for instance, by the demonstration of local NPY-IR neurons resistant to 6-OHDA pretreatment in, for example, the intestine (Lundberg et al., 1982b; see also Sundler et al., 1983).

In the present study we have used specific antisera with high affinity for porcine NPY and PYY, respectively, in RIA and for immunohistochemistry. Levels of NPY and PYY, as measured by RIA, were compared with the results of immunohistochemistry. Special care was given to possible cross-reaction between these peptides and a series of related peptides (APP, $\mathrm{BPP}, \gamma$-MSH, and FMRF-amide).

\section{Materials and Methods}

Immunohistochemistry. Male rats (body weight 150 to $250 \mathrm{gm}$ ) and juvenile pigs (body weight 25 to $30 \mathrm{~kg}$ ) were studied. The rats were anesthetized with Nembutal $(50 \mathrm{mg} / \mathrm{kg}$, i.p.) and perfused intracardially with ice-cold saline for $30 \mathrm{sec}$ followed by ice-cold $10 \%$ formalin (Pease, 1962 ) for $20 \mathrm{~min}$. The brain and peripheral tissues were dissected out and immersed in the same fixative for $90 \mathrm{~min}$. Alternatively, after the saline rinse, small tissue pieces from the brain and some peripheral organs were dissected out, sliced, and immersion-fixed for $2 \mathrm{hr}$ in an ice-cold phosphate buffer $(0.05 \mathrm{M}, \mathrm{pH} 7.4)$, containing $2 \%$ formalin and $0.25 \%$ parabenzoquinone (PBQ) (Lundberg et al., 1982a). The pigs were anesthetized with Nembutal $(50 \mathrm{mg} / \mathrm{kg}$, i.v.), and brain and peripheral tissues were immersed in either $10 \%$ formalin or the formalin/PBQ mixture described above for 2 to $4 \mathrm{hr}$. After either type of fixation the tissues were rinsed with buffered $5 \%$ sucrose for at least $24 \mathrm{hr}$ and then sectioned on a cryostat. Fourteen-micrometer thick sections were cut and incubated for $24 \mathrm{hr}$ at $+4^{\circ} \mathrm{C}$ with antisera to porcine NPY (102B), porcine PYY (69C) (Lundberg et al., 1982b), APP (68D), BPP (417; lot 615-R110-146-16, donated by Dr. R. Chance, Eli Lilly and Co., Indianapolis, IN), synthetic $\gamma-\mathrm{MSH}(1-11)(85 \mathrm{C})$, and synthetic FMRF-amide (469; donated by Prof. R. Elde, Department of Anatomy, University of Minnesota Medical School, Minneapolis, MN). The following working dilutions of antisera were used: NPY, 1:400; PYY, 1:100; APP, 1:200; BPP, 1:200; and FMRF-amide, 1:800. Following incubation for $24 \mathrm{hr}$ at $+4^{\circ} \mathrm{C}$ and rinsing, the sections were incubated with a fluorescein isothiocyanate (FITC) (Dakopats, Copenhagen, Denmark)-labeled swine-anti-rabbit antiserum diluted 1:10 for $30 \mathrm{~min}$ at $37^{\circ} \mathrm{C}$. The sections were subsequently rinsed, mounted in a mixture of glycerin and phosphate buffer containing $0.2 \%$ paraphenylenediamine (see Giloh and Sedat, 1982), and examined in a Zeiss fluorescence microscope equipped with filter for optimal FITC detection. To study the specificity of the immunostaining and cross-reactivity of the antisera with related peptides, adjacent sections were incubated with antisera that had been preabsorbed with various peptides for $24 \mathrm{hr}$ at $+4^{\circ} \mathrm{C}$ (see "Results"). The preabsorption experiments were repeated twice and coded sections were studied by two independent observers.

NPY and porcine PYY were obtained using the isolation procedure described earlier (Tatemoto, 1882a, b). Synthetic NPY was obtained from Bachem (Torrence, CA). APP and BPP were purified and generously donated by Prof. J. Kimmel (VA Medical Center, Kansas City, MO) and Dr. R. Chance. $\gamma$-MSH(1-11) and FMRF-amide were purchased from Peninsula Laboratories (Belmont, CA). APP(31-36) was obtained by custom synthesis from Merseyside Laboratories (Warrington, England).

Biochemical methods. NPY isolated from porcine brain (Tatemoto 1982a) was used for immunization and preparation of labeled tracer. For immunization, $280 \mu \mathrm{g}$ of NPY were coupled to $2.2 \mathrm{mg}$ of bovine thyroglobulin (Sigma Chemical Co., St. Louis, MO) by the addition of $53 \mu \mathrm{g}$ of 1-ethyl-3-dimethyl-aminopropylcarbodiimide (Sigma). The reaction was carried out in $0.4 \mathrm{ml}$ of $\mathrm{H}_{2} \mathrm{O}$ under gentle agitation for 20 $\mathrm{hr}$ at room temperature and terminated by the addition of $200 \mu \mathrm{l}$ of 2 M hydroxylamine (Merck, Darmstadt, Federal Republic of Germany). The reaction mixture was dialyzed twice against 2 liters of physiological saline. The conjugate concentration was adjusted to $70 \mu \mathrm{g}$ of peptide/ $\mathrm{ml}$. For immunization, this solution was emulsified with an equal volume of Freund's complete adjuvant. Each rabbit received doses corresponding to $50 \mu \mathrm{g}$ of peptide intradermally on the back at 30 to 40 sites. Booster doses of conjugate corresponding to $50 \mu \mathrm{g}$ of peptide were then given after about 2 months and then at monthly intervals by subcutaneous injections at the mamillary line of conjugate emulsified with Freund's incomplete adjuvant. Three or more booster injections were necessary to give good titers.

Iodination of NPY was carried out with the chloramine T procedure in a $0.1 \mathrm{M}$ phosphate buffer with a reaction time of $10 \mathrm{~min}(\mathrm{pH} \mathrm{7.5)}$, using Iodobeads (Pierce Chemical Co., Rockford, IL). For $1 \mathrm{nmol}$ of peptide, $0.5 \mathrm{mCi}$ of $\mathrm{NaI}^{125}$ was used. The reaction product was fractionated by high pressure liquid chromatography (HPLC) on a $\mu$ Bondapak (Waters Associates, Milford, MA) C-18 reversed phase silica gel column, using $35 \%$ acetonitrile and $0.04 \%$ trifluoroacetic acid in water as eluent. The eluted produce showed a complex elution pattern (there are five tyrosine residues in the molecule), and the peak with oligolabeled material was collected (Fig. 1).

For RIA, antiserum $102 \mathrm{~B}$ at $1: 20,000$ to $1: 50,000$ final dilution and about $5,000 \mathrm{cpm}{ }^{125} \mathrm{I}-\mathrm{NPY}$ was incubated for $24 \mathrm{hr}$ at $4^{\circ} \mathrm{C}$ in $225 \mu \mathrm{l}$ of buffer $(0.05 \mathrm{M}$ sodium phosphate, $\mathrm{pH} 7.5,0.15 \mathrm{M} \mathrm{NaCl}, 0.02 \%$ sodium azide, $0.1 \%$ gelatin, $0.1 \%$ bovine serum albumin (BSA), and $0.1 \%$ Triton $\mathrm{X}-100$ ). Alternatively, the extracts were incubated for $48 \mathrm{hr}$ with antiserum, followed by subsequent addition of tracer and incubation for another $72 \mathrm{hr}$. The incubation was terminated by the addition of $200 \mu \mathrm{l}$ of charcoal suspension $(2 \mathrm{gm}$ of Norite $\mathrm{A}$ in $100 \mathrm{ml}$ of $0.01 \mathrm{M}$ sodium phosphate mixed with an equal volume of $0.01 \mathrm{M}$ sodium phosphate buffer with $0.2 \mathrm{gm}$ of BSA and $0.2 \mathrm{gm}$ of Dextran T 70) After $10 \mathrm{~min}$, the tubes were centrifuged (Microfuge B, Beckman

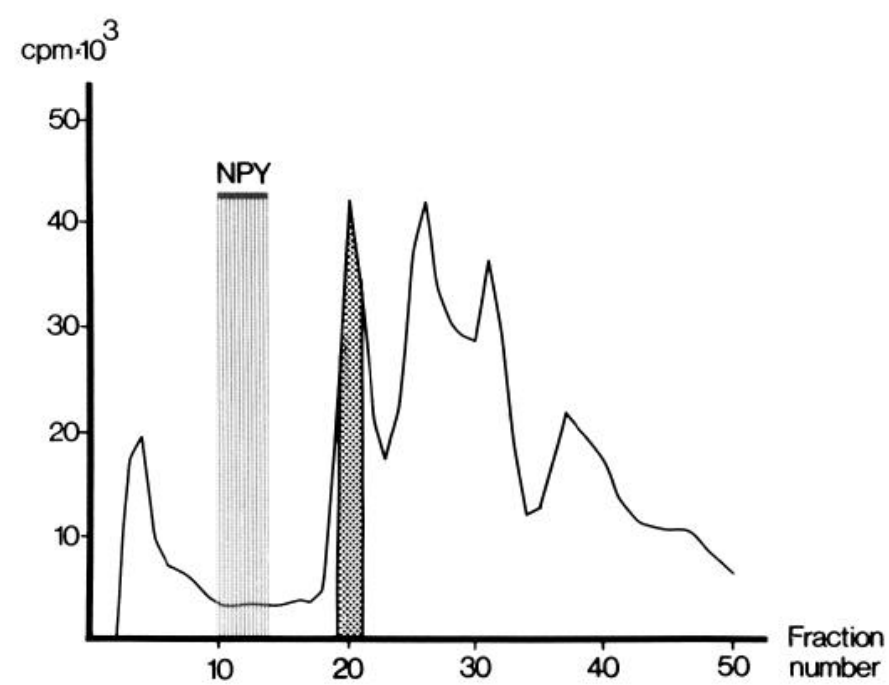

Figure 1. Elution pattern of radioactivity (volume, $10 \mu \mathrm{l}$ ) after labeling of NPY with the chloramine T procedure. Besides free iodide which elutes in the first few fractions, there are several peaks of radioactivity. There is probably progressive increase in the molecular ratio of iodine to peptide with increasing elution volume. In RIA, the early peak (shaded area) gave the best results. The elution volume of unlabeled NPY is also indicated. 
Instruments, Palo Alto, CA) for $2.5 \mathrm{~min}$, and $300 \mu \mathrm{l}$ of supernatant were counted in a gamma counter. A standard curve was prepared and the iodinated NPY was considered adequate, if the apparent $K_{\mathrm{D}}$ was less than $10^{-9} \mathrm{M}$. To study further the characteristics of the NPY antiserum, tryptic fragments of NPY (NPY(1-19), NPY(20-25), and NPY (26-33), each about $10 \mathrm{nmol}$ ) were prepared and isolated by HPLC, as described earlier (Tatemoto, 1982b).

Frozen specimens to be analyzed were cut into small fragments and added to a Potter-Elvehjelm homogenizer containing $20 \mathrm{vol}$ of $1 \mathrm{M}$ acetic acid kept at $95^{\circ} \mathrm{C}$. After $5 \mathrm{~min}$, the homogenizer was cooled, the tissues were homogenized, and then the homogenizer was heated to $95^{\circ} \mathrm{C}$ for another $5 \mathrm{~min}$. The homogenates were centrifuged at 10,000 $\times g$ for $20 \mathrm{~min}$, and the supernatants were collected and kept for a few days at $-90^{\circ} \mathrm{C}$ until analysis. The extracts were then separated on an SP-Sephadex C-25 cation exchanger prior to the RIA, as earlier described for analysis of PYY (Lundberg et al., 1982b; see also Bergström et al., 1983). A suitable number of ion exchange columns were prepared, using a $1-\mathrm{ml}$ ion exchanger in silanized Pasteur pipettes. The gel had previously been equilibrated in $0.018 \mathrm{M}$ pyridine $/ 0.1 \mathrm{M}$ formic acid, $\mathrm{pH}$ 3.3. One milliliter of extract was diluted with an equal volume of the same buffer and run through the column. The column was then washed twice with $2 \mathrm{ml}$ of the same buffer, $4 \mathrm{ml}$ of $0.35 \mathrm{M}$ pyridine formate (pH 4.4), and $0.8 \mathrm{M}$ pyridine formate of the same $\mathrm{pH}$. Finally, NPY was eluted with $4 \mathrm{ml}$ of $1.6 \mathrm{M}$ pyridine formate buffer, $\mathrm{pH} 4.4$, containing $0.005 \%$ Triton X-100. The eluates were evaporated in vacuo in a Savant-Vac (Hicksville, NY) vacuum concentrator. Of the total NPY recorded from rat vas deferens extracts, $94 \%$ eluted in the appropriate fraction and $5 \%$ eluted in the $0.8 \mathrm{~m}$ buffer wash. The recoveries of added NPY standard ( 2.4 to $8.4 \mathrm{pmol}$ ) from tissue extracts were 40 to $60 \%$. All figures are corrected for recovery.

Closer characterization of the measured NPY-like material was obtained through preparative HPLC on a $\mu$ Bondapak column. The column was eluted at $1 \mathrm{ml} / \mathrm{min}$ with a 50 -min linear gradient with 20 to $55 \%$ acetonitrile in $0.04 \%$ trifluoroacetic acid. For RIA, 1-min fractions were collected and evaporated in the Savant-Vac concentrator. RIA for PYY was performed as described earlier (Lundberg et al., 1982b). APP and $\gamma$-MSH assay conditions were similar to those for NPY.

\section{Results}

\section{Immunohistochemical analysis}

In the present study, attention was focused on some brain areas and peripheral tissues which, as shown in this and previous studies (Lundberg et al., 1982c; Allen et al., 1983; Hökfelt et al., 1973; 1983; Everitt et al., 1984), contain numerous NPYIR neurons (see below). These tissues were investigated on adjacent sections, using antisera to NPY and related peptides (see Fig. 2). Incubation with several of these antisera (raised against NPY, APP, BPP, $\gamma$-MSH, or FMRF-amide) resulted in very similar staining patterns in certain areas and tissues, for example vas deferens (Fig. 3) and the rostral nucleus tractus solitarii. However, the intensity of the staining could vary considerably between different antisera (Fig. 3, Table 1).

NPY antiserum 102B. NPY-IR neurons were abundant in both central and peripheral nervous systems of rat and pig. Thus, NPY-IR cells and/or fibers were seen in the cerebral cortex (Fig. 4, $a$ and b), hypothalamus (Fig. 4c), some areas of the medulla oblongata (e.g., nucleus tractus solitarii and lateral reticular nucleus) (Fig. 4d), sympathetic ganglia (Fig. 4e), vas deferens (Figs. $2 a$ and $5 a$ ), pancreas (Fig. 4f), and colon (Fig. $4 g$ ). No endocrine cells in the pancreas (Fig. 4f) and colon (Fig. $4 g$ ) were NPY-IR.

Preabsorption results are summarized in Table I (A to C). Absorption of NPY antiserum with NPY abolished the immunostaining (Fig. $5 b$ ), whereas absorption with 100 - to 1000 fold excess of APP (Fig. 5c), APP(31-36) (Fig. 5d), BPP, $\gamma$ MSH, FMRF-amide (Fig. 5e), PYY (Fig. 5f), and neurotensin had no effect (Table I, Fig. 5). In RIA the NPY antiserum did not show any significant $(<0.1 \%)$ cross-reactivity to APP, PYY, FMRF-amide, $\gamma$-MSH, and neurotensin. The antiserum seems to be directed to the $\mathrm{NH}_{2}$-terminal end of the peptide, since the tryptic fragment NPY(1-19) showed high ( $\sim 20 \%)$ competitive affinity, whereas the fragments (NPY(20-25), NPY(2633)) did not cross-react. The NPY antiserum showed similar cross-reactivity to natural and synthetic porcine NPY (Fig. 6).

$A P P$ antiserum $(68 D)$. The APP antiserum stained nerves with a distribution very similar to that observed with the NPY antiserum (Fig. $3 b$ ). In addition, some endocrine cells in the Langerhans islets of the pancreas, but not in the colon, were APP-IR. The APP immunoreactivity in nerves was strongly reduced by NPY preabsorption but not by any of the other PPrelated peptides (Table I). However, the APP staining of endocrine cells in the pancreas was not reduced by NPY (Table I). In RIA, the APP antiserum was partially displaced by NPY at 10 -fold higher concentrations (Fig. 7), and there was also slight $(1 \%)$ cross-reactivity with BPP. There was no $(<0.1 \%)$ cross-reactivity with PYY or neurotensin.

$B P P$ antiserum (417). The BPP antiserum stained many nerves with a distribution similar to those visualized with the NPY and APP antisera (Fig. 3c). In addition, many endocrine cells of the colon and pancreas were BPP-IR. Preabsorption with NPY, PYY, APP, and APP(31-36) abolished the BPP staining of nerves, whereas the BPP immunoreactivity in endocrine cells did not seem to be affected by any PP-related peptide except BPP (Table I). $\left.{ }^{125} I\right] N P Y$ bound weakly to the BPP antiserum (with $K_{\mathrm{D}}$ of only $2 \times 10^{-8} \mathrm{M}$ against $<10^{-10} \mathrm{M}$ with $\left[{ }^{125} \mathrm{I}\right] \mathrm{BPP}$; it was also necessary to use 25 times higher antiserum concentration to observe binding of $\left.\left[{ }^{125} \mathrm{I}\right] \mathrm{NPY}\right)$. No analysis of tissue levels has been made using this antiserum.

$P Y Y$ antiserum (69 C). The PYY antiserum induced staining of small numbers of nerves restricted to nucleus tractus solitarii and adjacent regions and to the ventral parts of the medulla oblongata of the rat. In addition, the PYY antiserum stained endocrine cells in rat pancreas and in the colon of both the rat and the pig (Fig. 4h). No PYY-IR nerves were seen in the hypothalamus or in the vas deferens (Fig. $3 d$ ). The PYY staining of nerves or endocrine cells was not abolished by preabsorption with NPY or any other PP-related peptide (Table I). However, APP(31-36) preabsorption reduced the intensity of the PYY immunoreactivity in both nerves and endocrine cells (Table I). In RIA the PYY antiserum had a slight crossreactivity to BPP $(1 \%)$ and to NPY $(0.5 \%)$, but not to any other PP-related peptide $(<0.1 \%)$.

$\gamma-M S H$ antiserum $(85 \mathrm{C})$. The $\gamma$-MSH antiserum stained nerves in areas similar to those stained by the NPY antiserum (Fig. $3 f$ ), although the immunostaining was often weaker in the rat cortex. In addition, many endocrine cells of the pancreas and colon reacted with this antiserum. Preabsorption of the $\gamma$ MSH antiserum with NPY, APP, APP(31-36), BPP, PYY, and FMRF-amide markedly reduced or abolished most of the $\gamma$ MSH staining of nerves and colonic endocrine cells. The $\gamma$ MSH staining of pancreatic endocrine cells was markedly reduced by APP, BPP, and PYY preabsorption, but not using preabsorption with NPY, APP(31-36), or FMRF-amide. In RIA, the $\gamma$-MSH antiserum did not cross-react to any significant extent $(<0.1 \%)$ with NPY, APP, or FMRF-amide. In 85 times higher concentrations the antiserum did not recognize $\left[{ }^{125} \mathrm{I}\right] \mathrm{NPY}$.

FMRF-amide antiserum (469). The FMRF-amide antiserum stained many nerves in the central and peripheral nervous systems (Fig. $3 e$ ) with an NPY-like distribution in addition to endocrine cells in the pancreas and colon. Preabsorption of the FMRF-amide antiserum with NPY, APP, BPP, PYY, and $\gamma$ $\mathrm{MSH}$ markedly reduced or abolished the immunostaining of both nerves and endocrine cells (Table I).

\section{Biochemical analysis}

The detection limit of the RIA for NPY using 24-hr incubation was $\sim 50 \mathrm{fmol} /$ tube, whereas sequential addition of the 


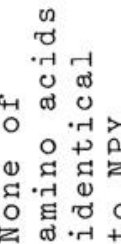

离

व $\cdot-4>$

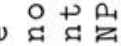

० छ त्ठ

ह

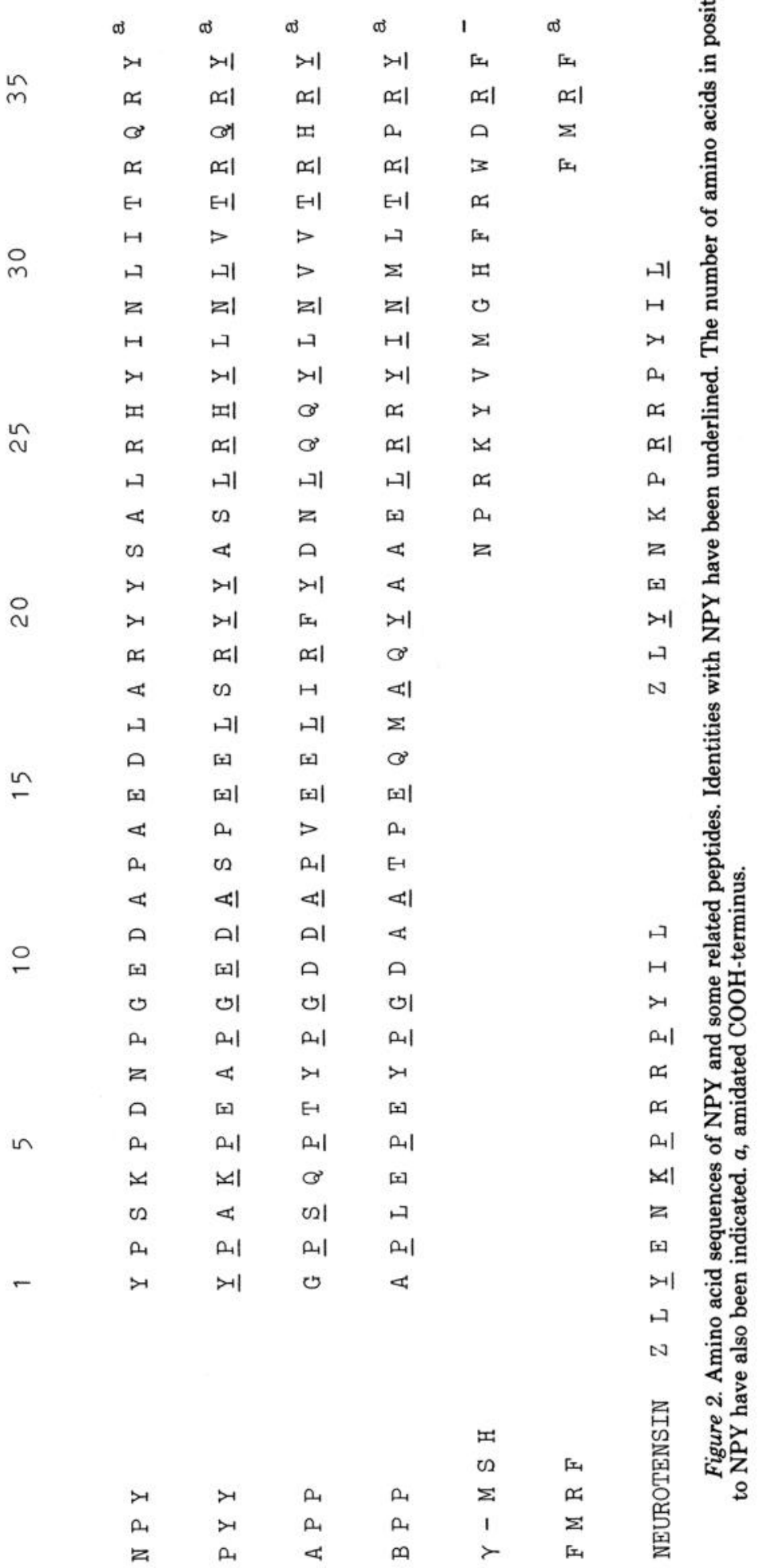



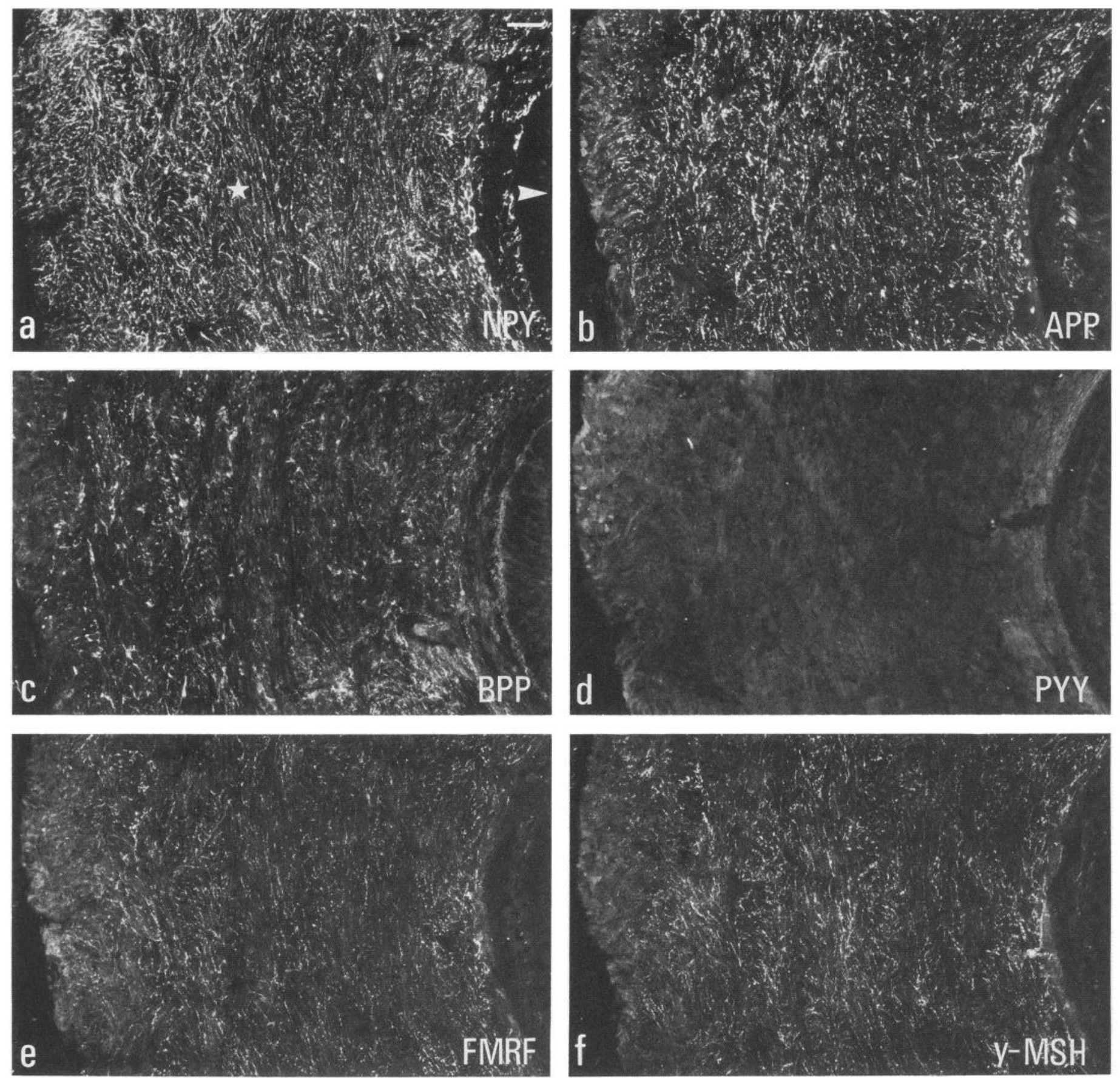

Figure 3. Immunofluorescence micrographs of semiconsecutive sections from the rat vas deferens after incubation with antisera to NPY (a), APP antiserum (b), BPP antiserum (c), PYY antiserum $(d)$, FMRF-amide antiserum $(e)$, and $\gamma$-MSH antiserum $(f)$. The bar indicates $50 \mu$ m. All micrographs have the same magnification.

tracer increased the sensitivity to about $10 \mathrm{fmol} /$ tube (Fig. 6). Tissue extracts were fractioned on ion exchange columns prior to RIA analysis. The relevant fractions caused concentrationdependent displacement of $\left[{ }^{125} \mathrm{I}\right] \mathrm{NPY}$. The displacement curves for rat vas deferens were parallel to those of the standard (Fig. 6).

HPLC analysis of NPY-IR material from pig and rat cortex and vas deferens revealed an elution volume very similar to that of standard natural porcine NPY. Material from the rat peaked slightly earlier than did porcine NPY (Fig. 8, $a$ and $b$ ). In the rat cortex, there was also evidence for some NPY-IR peaks, which eluted earlier than the standard (Fig. 8). The major NPY peaks were clearly separated from that of standard natural porcine PYY.

The levels of NPY and PYY in some brain areas and peripheral organs of the pig and rat, as measured by RIA, are given in Table II. Especially high levels of NPY were observed in the hypothalamus and vas deferens of the rat and in the cortex of the pig. The NPY levels in the cerebellum were below or close to the detection limit. In the rat significant amounts of PYY in the central nervous system, assuming a cross-reaction in the RIA with NPY of $0.5 \%$ (i.e., low NPY to PYY ratio), were observed in the nucleus of the tractus solitarius (Table I). On the other hand, high levels of PYY were found in the pancreas, 
TABLE I

Effects of preabsorption with various peptides at different concentrations for $24 \mathrm{hr}$ at $+4^{\circ} \mathrm{C}$ on the intensity of the immunofluorescence staining using NPY antiserum (102B), APP antiserum (68D), BPP antiserum (417), PYY antiserum (69C), $\gamma$-MSH antiserum (85C), and FMRF-amide antiserum (469)

The intensity of the immunostaining in nerve endings and endocrine cells of various tissues of the rat (i.e., nerve endings in parietal cortex, paraventricular nucleus of the hypothalamus, nucleus tractus solitarii of the medulla oblongata, vas deferens, and endocrine cells in the pancreatic islets of Langerhans and colon) has been analyzed in the fluorescence microscope and graded in arbitrary units from 0 (no staining) to 5 (very intense staining). The mean units from two separate experiments are given.

TABLE IA

\begin{tabular}{|c|c|c|c|c|c|c|c|c|c|c|c|c|}
\hline \multirow[b]{2}{*}{ Antiserum } & \multicolumn{6}{|c|}{ Cortex } & \multicolumn{6}{|c|}{ Hypothalamus } \\
\hline & NPY & APP & BPP & PYY & $\gamma$-MSH & $\begin{array}{l}\text { FMRF- } \\
\text { amide }\end{array}$ & NPY & APP & BPP & PYY & $\gamma$-MSH & $\begin{array}{l}\text { FMRF- } \\
\text { amide }\end{array}$ \\
\hline $\begin{array}{l}\text { Preabsorption: - } \\
\text { (M) }\end{array}$ & 5 & 4 & 2 & 0 & 2 & 5 & 5 & 4 & 3 & 0 & 4 & 5 \\
\hline NPY $10^{-7}$ & 1 & & & & & & 1 & & & & 1 & \\
\hline $10^{-6}$ & 0 & & & & & & 0 & & & & & \\
\hline $10^{-5}$ & & 1 & 0 & & 0 & 0 & & 1 & 0 & & & 0 \\
\hline APP $10^{-7}$ & & 0 & & & & & & 0 & & & & \\
\hline $10^{-6}$ & & 0 & & & & & & 0 & & & & \\
\hline $10^{-5}$ & 5 & & 0 & & 0 & 1 & 5 & & 0 & & 0 & 1 \\
\hline $\operatorname{BPP} 10^{-7}$ & & & & & & & & & 0 & & & \\
\hline $10^{-6}$ & & & & & & & & & 0 & & & \\
\hline $10^{-5}$ & 5 & 3 & & & 0 & 0 & 5 & 3 & & & 0 & 0 \\
\hline PYY $10^{-7}$ & & & & & & & & & & & & \\
\hline $\begin{array}{l}10^{-6} \\
10^{-5}\end{array}$ & 5 & 4 & 0 & & & 2 & 5 & 4 & & & 0 & ? \\
\hline$\gamma$-MSH $10^{-7}$ & & & & & 0 & 4 & 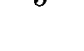 & 4 & & & 0 & 2 \\
\hline $10^{-6}$ & & & & & 0 & & & & & & 0 & \\
\hline $10^{-5}$ & 5 & 4 & 2 & & & 1 & 5 & 4 & 3 & & & 1 \\
\hline FMRF-amide $10^{-7}$ & & & & & & 3 & & & & & & 3 \\
\hline $10^{-6}$ & & & & & & 1 & & & & & & 1 \\
\hline $10^{-5}$ & & & & & & 0 & & & & & & 0 \\
\hline $10^{-4}$ & 5 & 4 & 2 & & 0 & & 5 & 4 & 3 & & 0 & \\
\hline $\operatorname{APP}(31-36) 10^{-4}$ & 5 & 4 & 0 & & 0 & 4 & 5 & 4 & 0 & & 1 & 4 \\
\hline \multicolumn{13}{|c|}{ TABLE IB } \\
\hline \multirow{2}{*}{ Antiserum } & \multicolumn{6}{|c|}{ Medulla Oblongata } & \multicolumn{6}{|c|}{ Vas Deferens } \\
\hline & NPY & APP & $\mathrm{BPP}$ & PYY & $\gamma$-MSH & $\begin{array}{l}\text { FMRF- } \\
\text { amide }\end{array}$ & NPY & APP & BPP & PYY & $\gamma$-MSH & $\begin{array}{l}\text { FMRF- } \\
\text { amide }\end{array}$ \\
\hline $\begin{array}{l}\text { Preabsorption: - } \\
\text { (M) }\end{array}$ & 4 & 3 & 2 & 2 & 3 & 4 & 5 & 4 & 3 & 0 & 4 & 5 \\
\hline NPY $10^{-7}$ & 0 & & & & & & 0 & & & & & \\
\hline $10^{-6}$ & 0 & & & & & & 0 & & & & & \\
\hline $10^{-5}$ & & 1 & 0 & 2 & 1 & 0 & & 1 & 0 & & 1 & 0 \\
\hline APP $10^{-7}$ & & 0 & & & & & & 0 & & & & \\
\hline $10^{-6}$ & & 0 & & & & & & 0 & & & & \\
\hline $10^{-5}$ & 4 & & 0 & 2 & 1 & 1 & 5 & & 0 & & 0 & 0 \\
\hline $\operatorname{BPP} 10^{-7}$ & & & 0 & & & & & & 0 & & & \\
\hline $10^{-6}$ & & & 0 & & & & & & 0 & & & \\
\hline $10^{-5}$ & 4 & 3 & & 2 & 1 & 1 & 5 & 3 & & & 0 & 0 \\
\hline PYY $10^{-7}$ & & & & 0 & & & & & & & & \\
\hline $10^{-6}$ & & & & 0 & & & & & & & & \\
\hline $10^{-5}$ & 4 & 3 & 0 & & 1 & 2 & 5 & 4 & 0 & & 0 & 1 \\
\hline$\gamma$-MSH $10^{-7}$ & & & & & 0 & & & & & & 0 & \\
\hline $10^{-6}$ & & & & & 0 & & & & & & 0 & \\
\hline $10^{-5}$ & 4 & 3 & 2 & 2 & & 1 & 5 & 4 & 2 & & & 1 \\
\hline FMRF-amide $10^{-7}$ & & & & & & 2 & & & & & & 3 \\
\hline $10^{-6}$ & & & & & & 0 & & & & & & 0 \\
\hline $10^{-5}$ & & & & & & & & & & & & \\
\hline $10^{-4}$ & 4 & 3 & 2 & 2 & 1 & & 5 & 4 & 2 & & 0 & \\
\hline $\operatorname{APP}(31-36) 10^{-4}$ & 4 & 3 & 0 & 1 & 2 & .4 & 5 & 4 & 0 & & 2 & 4 \\
\hline
\end{tabular}

duodenum, and colon (Table II). RIA for APP revealed no detectable immunoreactivity in brain, vas deferens, or a variety of other rat tissues, although the APP antiserum had high affinity for $\operatorname{APP}\left(K_{\mathrm{D}}<10^{-10} \mathrm{M}\right)$.

\section{Discussion}

The present findings establish NPY as a naturally occurring neuropeptide in widespread systems in the CNS and periphery. 
TABLE I-continued

TABLE IC

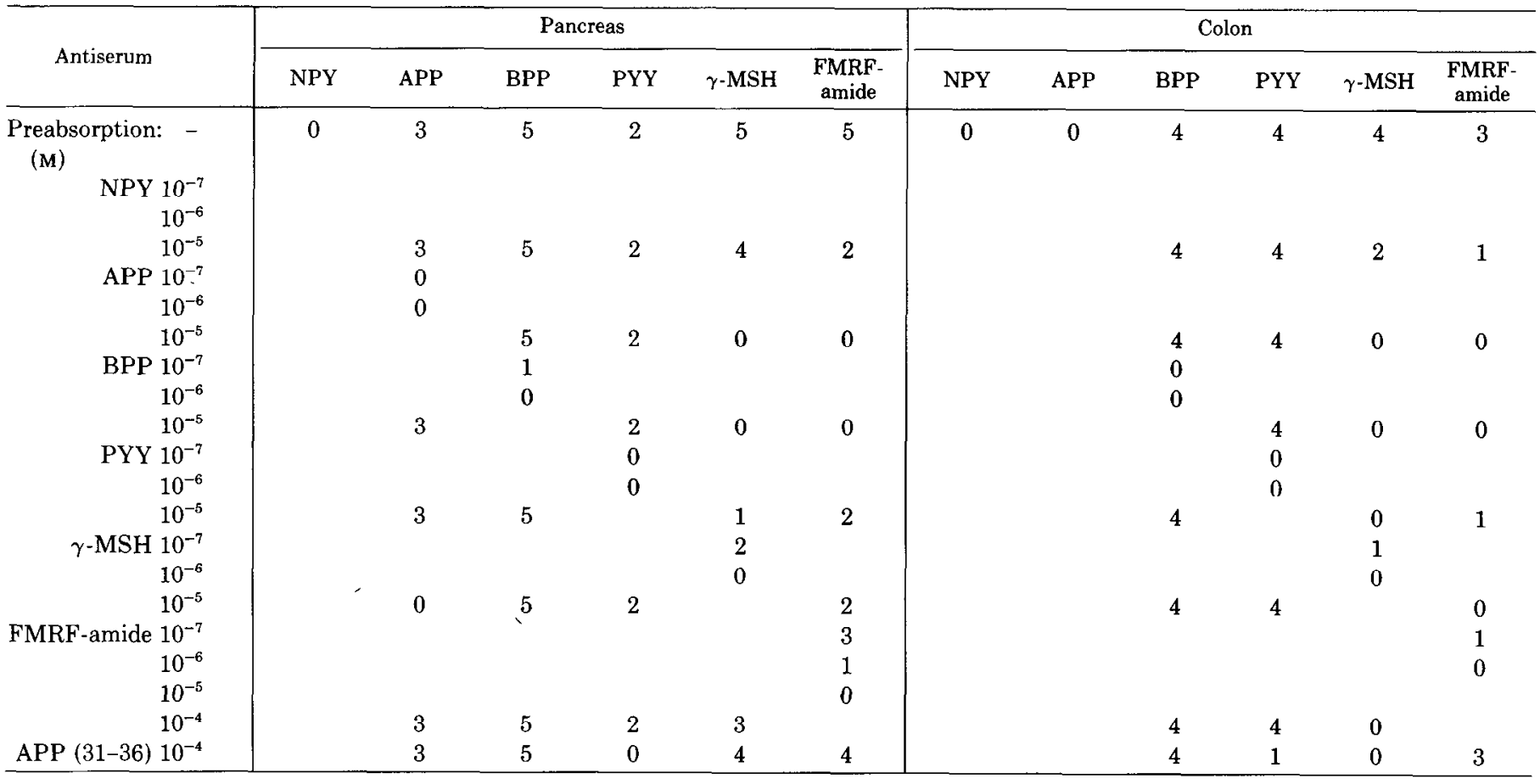

This conclusion is based on the following observations. (1) The NPY antiserum does not cross-react with any other PP-like peptide tested, neither as analyzed with RIA nor with the high concentrations of antiserum used in immunohistochemistry. The lack of significant cross-reactivity between the NPY antiserum and other PP peptides was further substantiated by the observation that the antiserum did not stain endocrine cells of the pancreas (i.e., PP cells) or colon (PYY cells), i.e., structures which contain comparatively high levels of PP-related peptides. (2) There was a good correlation between the density and distribution pattern of NPY neurons, as observed with immunofluorescence histochemistry, and of the concentration of NPY as measured by RIA. This is in marked contrast to the results with the APP antiserum, which gives rise to strong immunostaining but fails, when used in RIA, to react with any endogenous material (see also Gu et al., 1983). (3) There was identical chromatographic behavior in HPLC analysis of material extracted from porcine vas deferens and brain reacting in RIA for NPY, and the authentic standard. HPLC analysis of material from the rat indicated some heterogeneity but with the main peak eluting rather close to porcine NPY. There was a very clear chromatographic separation from PYY. (4) The fact that other antisera (against PP peptides, $\gamma-\mathrm{MSH}$, and FMRF-amide) not primarily directed against NPY gave ne1ronal staining patterns similar to those obtained with NPY antiserum might be explained by cross-reaction with NPY at the immunocytochemical level. Particularly, the APP antiserum showed marked cross-reaction with NPY in RIA. It therefore seems likely that earlier reports on neuronal staining with antisera against APP or BPP (Lorén et al., 1979; Lundberg et al., 1980, 1982a; Hunt et al., 1981; Jacobowitz and Olschowka, 1982) in several areas can be explained by reaction with NPY.

Recently, J. R. Kimmel (personal communication) has succeeded in purifying rat $P P$ and raised antiserum against the peptide. Preliminary work with this antiserum has revealed a moderately strong staining of rat neurons with a distribution similar to the NPY-IR ones. This staining was blocked by NPY $\left(10^{-5} \mathrm{M}\right)$, whereas NPY-like immunoreactivity (102B) was not affected by preabsorption with rat PP (unpublished observations).

The levels of NPY that we have measured in certain areas of rat brain are in partial agreement with those recently reported by Allen et al. (1983). Thus, they found about $180 \mathrm{pmol} /$ gm of wet weight in cortex and 700 to $1000 \mathrm{pmol}$ in hypothalamus. However, our levels were lower in the caudate, where they reported the NPY content to be more than $300 \mathrm{pmol}$ compared to our 75 to $150 \mathrm{pmol}$, and in cerebellum, which they reported as $27 \mathrm{pmol}$, compared to our values close to the detection limit $(<1$ to $4 \mathrm{pmol} / \mathrm{gm})$. One possible explanation for our lower levels is that we are using an ion exchange procedure prior to the RIA, which removes material interfering in the RIA.

FMRF-amide and $\gamma$-MSH have a certain structural homology since they both terminate in Arg-Phe-amide. Furthermore, the cross-reaction of the $\gamma$-MSH and FMRF-amide antisera to the PP-related peptides may be explained by the structural similarities of the C-terminal Arg-Phe- $\mathrm{NH}_{2}$ and Arg-Tyr- $\mathrm{NH}_{2}$ sequences. However, it should be remembered that FMRFamide has been isolated from a mollusc (Price and Greenberg, 1977) and that the corresponding peptide in rat brain may be structurally different. Dockray and Williams (1983) found evidence for two peptides reacting with FMRF-amide antiserum in rat brain, and more recently they identified a pentapeptide, LPLRF-amide (Leu-Pro-Leu-Arg-Phe- $\mathrm{NH}_{2}$ ) in chicken brain (Dockray et al., 1983). The FMRF-amide antiserum used by Dockray and Williams (1983) showed considerable cross-reactivity with APP but not with NPY under RIA conditions. Unfortunately, we do not have corresponding information for the FMRF-amide antiserum used here.

The immunohistochemical observation of a cross-reactivity of NPY for the $\gamma$-MSH antiserum was not supported by crossreaction in the RIA. Direct testing to determine whether $\left[{ }^{125} \mathrm{I}\right]$ NPY was bound to the antiserum was negative. Thus, there is no direct evidence that some minor population of antibodies in the $\gamma-\mathrm{MSH}$ antiserum is reacting with NPY. This observation stresses the importance of preabsorption controls in immuno- 

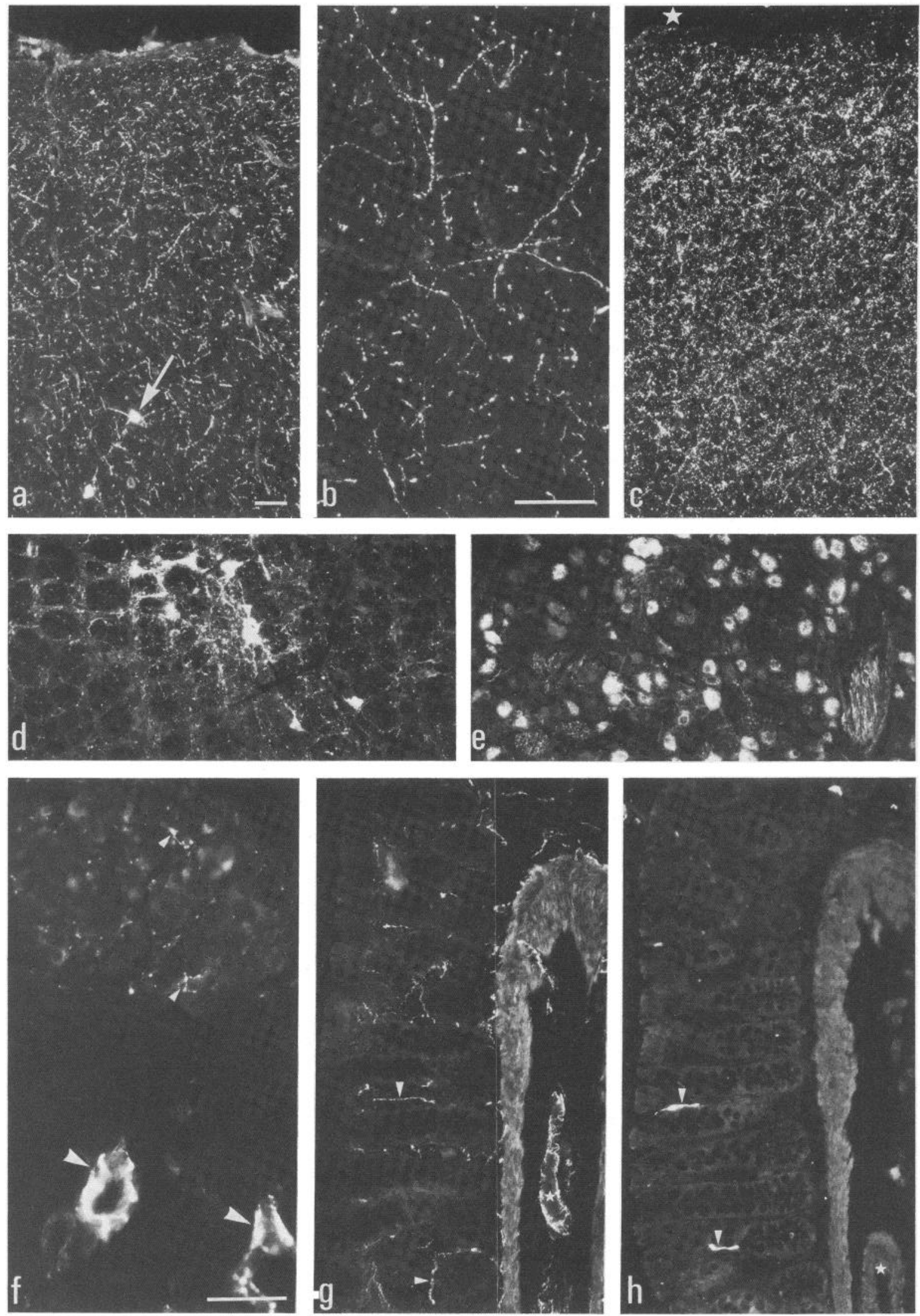

Figure 4. Immunofluorescence micrographs of the pig cerebral cortex ( $a$ and $b$ ), pig hypothalamus (periventricular area) (c), rat lateral reticular nucleus $(d)$, pig stellate ganglion $(e)$, rat pancreas $(f)$, and rat colon $(g$ and $h)$ after incubation with antiserum to NPY $(a$ to $g)$ and PYY $(h)$. The arrow in $a$ indicates NPY-IR cell body. The large arrowheads in $f$ indicate strongly fluorescent perivascular nerves and the small arrowheads indicate NPY-IR nerves in the Langerhans islets. Arrowheads in $g$ indicate NPY-IR nerves and those in $h$ indicate PYY-IR endocrine cells. $g$ and $h$ represent consecutive sections and small white stars indicate a submucosal artery for orientation. Bars indicate $50 \mu \mathrm{m}$. 

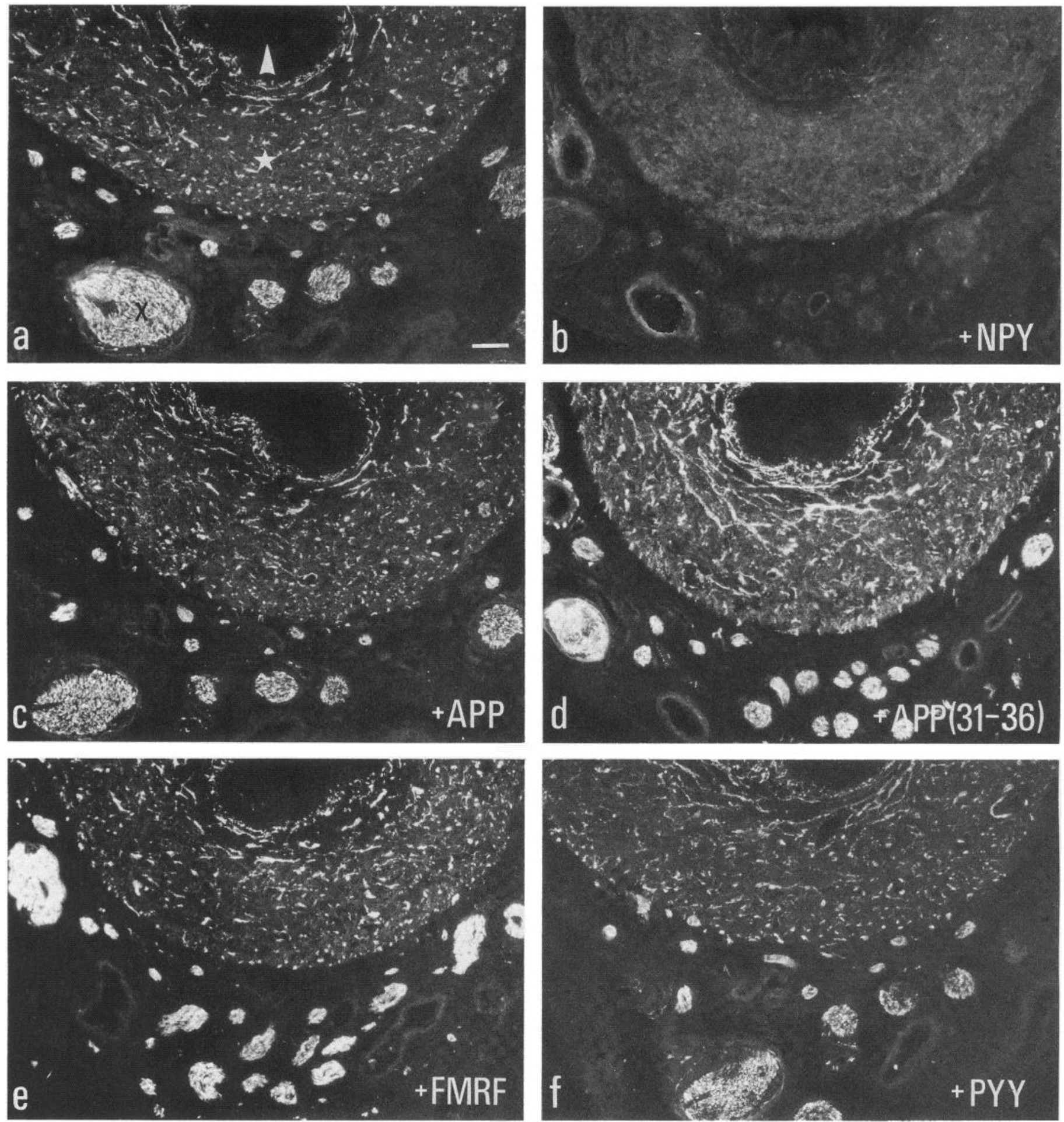

Figure 5. Immunofluorescence micrograph of vas deferens of a castrated pig after incubation with antiserum of NPY (a), NPY antiserum preabsorbed with $10^{-8} \mathrm{M}$ NPY $(b)$, NPY antiserum preabsorbed with $10^{-5} \mathrm{M}$ APP $(c)$, NPY antiserum preabsorbed with 10 $0^{-4} \mathrm{M}$ APP $(31-36)(d)$, NPY antiserum preabsorbed with $10^{-4}$ M FMRF-amide (e), and NPY antiserum preabsorbed with $10^{-5} \mathrm{M}$ PYY $(f)$. The arrowhead and star in $a$ indicate the lumen and the smooth muscle layer, respectively. The $X$ in $a$ denotes one of many small NPY-IR nerve trunks. The bar indicates $50 \mu \mathrm{m}$. All micrographs have the same magnification.

histochemical analysis even if RIA with many fold higher dilutions of antiserum does not reveal any significant crossreactivity. This kind of problem is probably going to be more acute, if the immunostained peptide occurs in large quantity. On the other hand, when cross-reactivity was observed in RIA it also seemed to extend to immunohistochemistry. The difficulties encountered here might have been avoided if more selective antibodies with reasonable affinity had been available to us.

The presence of PYY immunoreactivity in endocrine cells of the pancreas and intestine of several species confirms earlier results (Lundberg et al., 1982b). Here, PYY immunoreactivity was also seen in nerve fibers of the brainstem of the rat. This did not seem to be due to cross-reaction with NPY. RIA also 
showed PYY levels above the threshold in this region. Since the topographical distribution of the PYY-IR nerves seemed to be different from that of NPY, there may be separate neurons containing PYY-like peptide in the brainstem.

The staining of cells in the pancreas with APP antiserum was not reduced by preabsorption with NPY, BPP, or PYY, which may suggest the occurrence of other PP-related peptides. The BPP staining of endocrine cells in the colon was resistant

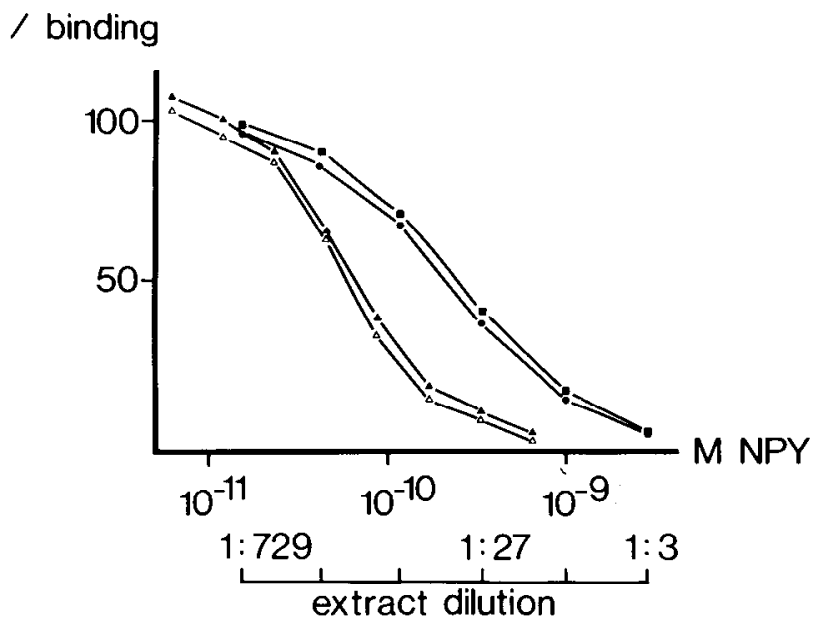

Figure 6. Cross-reactivity of the NPY antibody with synthetic porcine NPY (solid triangles), or natural porcine NPY (open triangles) as indicated by displacement of ${ }^{125}$ I-labeled porcine NPY. The increased sensitivity of sequential addition $\left(3+2\right.$ days incubation) of $\left[{ }^{125} \mathrm{I}\right] \mathrm{NPY}$ to the assay system (triangles) is illustrated since 24-hr incubation (solid circles) yields a standard curve shifted to the right. Parallel displaccment of NPY binding by a rat vas deferens extract dilution below (solid triangles) is also shown.

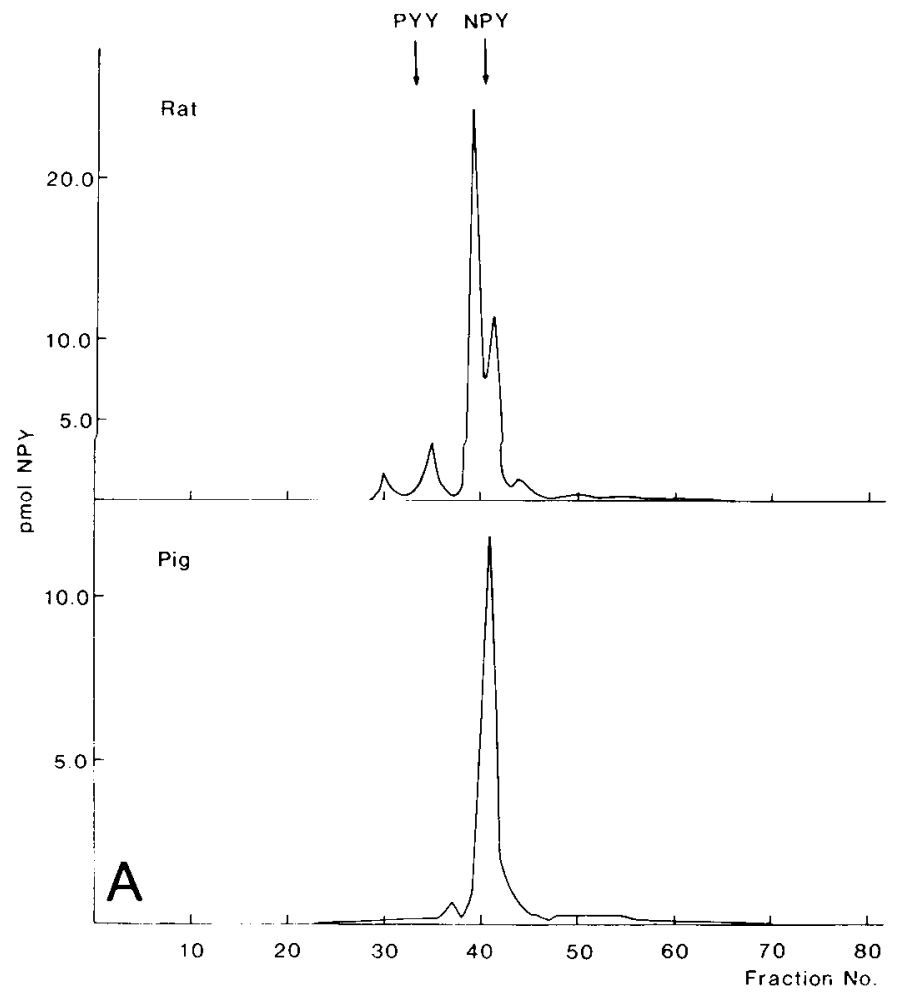

to absorption with the other PP-related peptides, suggesting that a PP-like substance is present in the intestine in addition to PYY and NPY. Whether the PYY- and BPP-IR cells are identical or represent two different populations of endocrine cells remains to be elucidated. The $\gamma$-MSH and FMRF-amide staining of endocrine cells was also affected by several PPrelated peptides, suggesting cross-reactivity with PP cells in the pancreas and PYY cells (and possibly PP cells) in the colon.

In conclusion, the present findings point to a high degree of structural complexity and diversity of PP-like peptides in neurons and endocrine cells. NPY appears as an important neuropeptide considering both its wide distribution and high levels. Although the present results do not support a major occurrence

\section{$\%$ binding APP 68 D}

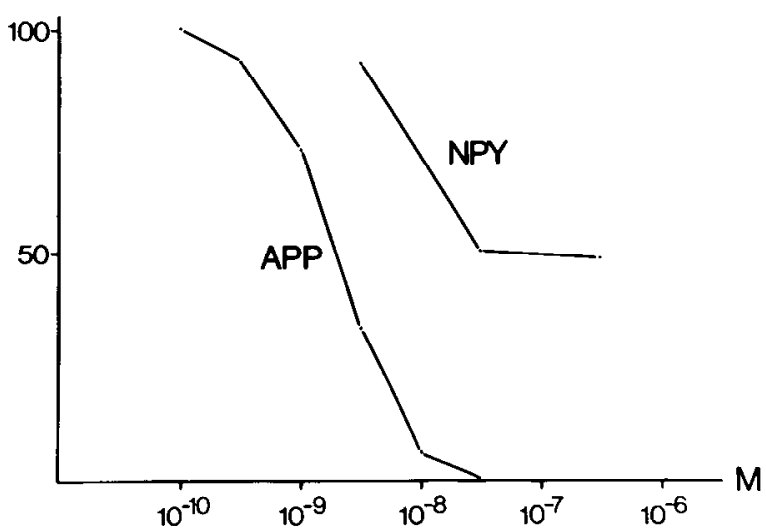

Figure 7. Cross-reactivity of the APP antibody with NPY, as indicated by inhibition of ${ }^{125}$ I-labeled APP binding by increasing concentrations of NPY.

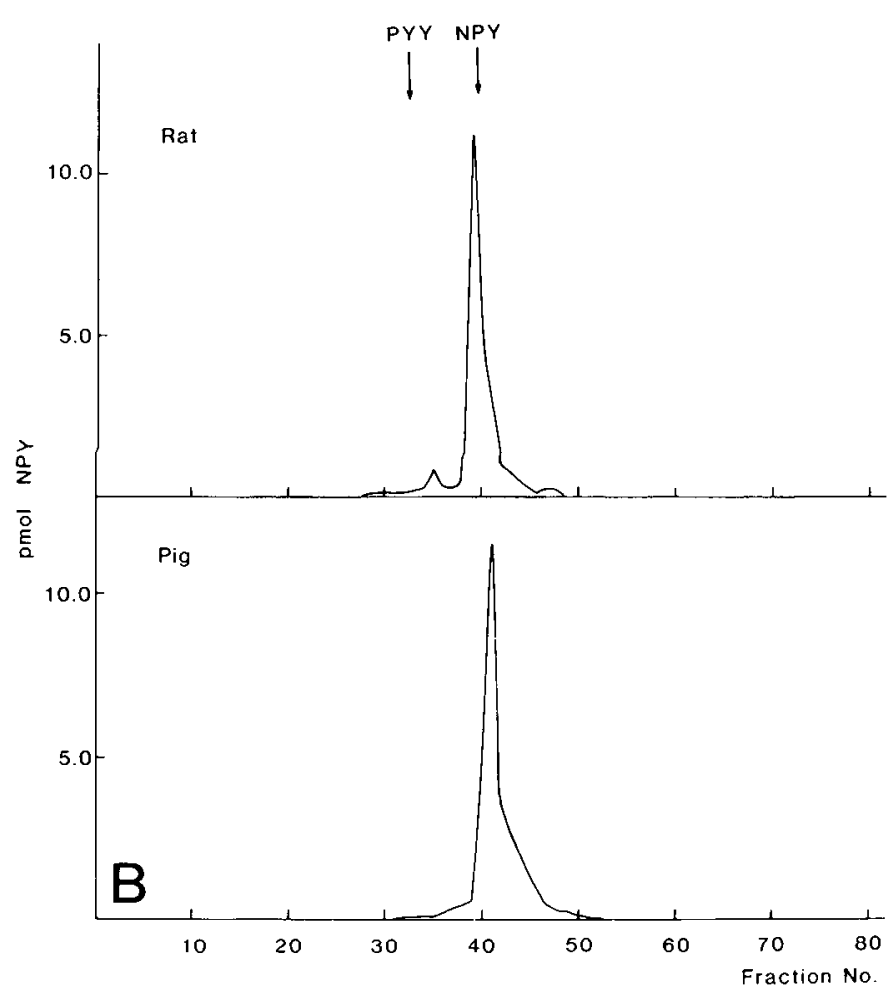

Figure 8. HPLC chromatograms of immunoreactive NPY from rat and pig cortex $(A)$ as well as rat and pig vas deferens $(B)$. The elution positions of standard (natural) porcine NPY and PYY are also indicated. Values represent picomoles of NPY per fraction. 
TABLE II

Distribution of NPY-and PYY-IR in various brain areas and peripheral tissues of the rat and pig

Data are given as picomoles per gram of tissue with the range indicated. There were two to six samples in each group.

\begin{tabular}{|c|c|c|c|c|}
\hline \multirow{2}{*}{ Brain Area } & \multicolumn{2}{|r|}{ NPY } & \multicolumn{2}{|c|}{ PYY } \\
\hline & Rat & Pig & Rat & Pig \\
\hline \multirow[t]{2}{*}{ Cortex } & $60-163$ & $517-1100(\text { par })^{a}$ & $<1$ & $4-7$ \\
\hline & & $600-713$ (occ) & & $1-10$ \\
\hline \multirow[t]{3}{*}{ Hypothalamus } & $558-685$ & $160-220$ (ant) & 3 & $3-16$ \\
\hline & & $181-247$ (med) & & $3-24$ \\
\hline & & $38-53$ (post) & & $1-9$ \\
\hline N. caudatus & $77 \cdots 148$ & 134149 & $<1$ & 2 \\
\hline Putamen & & $161-198$ & & $2-9$ \\
\hline Cerebellum & $<1-4$ & $<1-8$ & $<1-4$ & 3 \\
\hline NTSA 1 & $58-88$ & $12-25$ (rostr) & $11-13$ & $4-8$ \\
\hline N T S A 2 & $115-160$ & $18-42$ & $9-13$ & $1-3$ \\
\hline L. ceruleus & & $26-105$ & & $1-2$ \\
\hline N T V & & $264-462$ & & \\
\hline Vas deferens & $810-2028$ & $215-228$ & & $5-9$ \\
\hline Pancreas & & $48-56$ & $68-259$ & $36-48$ \\
\hline Duodenum & & $58-79$ & $12-17$ & $100-810$ \\
\hline Colon & & $5-11$ & $710-1312$ & $280-856$ \\
\hline
\end{tabular}

a The abbreviations used are: ant, anterior; med, medial; occ, occipital; par, parietal; post, posterior; rostr, rostral.

of other members of the PP family in the nervous system, this should be further analyzed. In the gastrointestinal tract, peptides of the PP family are present in at least three systems, with PP proper, NPY, and PYY, respectively. Clarification of the complicated occurrence of $\mathrm{PP}$-related peptides will require knowledge about the protein prohormones and their processing to smaller molecular forms and the access to specific antibodies for immunohistochemistry.

\section{References}

Allen, Y. S., T. E. Adrian, J. M. Allen, K. Tatemoto, T. J. Crow, S. R. Bloom, and J. M. Polak (1983) Neuropeptide Y distribution in rat brain. Science 221: 877-879.

Bergström, L., I. Christensson, R. Folkesson, B. Stenström, and L. Terenius (1983) An ion exchange chromatography and radioimmunoassay procedure for measuring opioid peptides and substance $\mathrm{P}$. Life Sci. 33: 1613-1619.

Dockray, G. J., and R. G. Williams (1983) FMRF-amide-like immunoreactivity in rat brain. Development of a specific radioimmunoassay and its application in studies of distribution and chromatographic properties. Brain Res. 266: 295-303.

Dockray, G. J., J. R. Reeve, Jr., J. Shirley, R. J. Gayton, and C. S. Bainard (1983) A novel active pentapeptide from chicken brain identified by antibodies to FMRF-amide. Nature 305: 328-330.

Everitt, B., T. Hökfelt, L. Terenius, K. Tatemoto, V. Mutt, and M. Goldstein (1984) Differential co-existence of neuropeptide Y (NPY)like immunoreactivity with catecholamines in the central nervous system of the rat. Neuroscience, in press.

Giloh, H., and J. W. Sedat (1982) Fluorescence microscopy: Reduced photobleaching of rhodamine and fluorescein protein conjugates by $n$-propyl gallate. Science 271: 1252-1255.

Gu, J., T. E. Adrian, K. Tatemoto, J. M. Polak, J. M. Allen, and S. R Bloom (1983) Neuropeptide tyrosine (NPY), a major cardiac neuropeptide. Lancet 1: 1008 . 1010.

Hökfelt, T., K. Fuxe, M. Goldstein, and T. H. Joh (1973) Immunohistochemical localization of three catecholamine-synthetizing enzymes: Aspects on methodology. Histochemie 33: 231-254.

Hökfelt, T., J. M. Lundberg, L. Terenius, G. Jancsó, and J. Kimmel (1981) Avian pancreatic polypeptide (APP) immunoreactive neurons in the spinal cord and spinal trigeminal nucleus. Peptides 2: 82-87.

Hökfelt, T., J. M. Lundberg, K. Tatemoto, V. Mutt, L. Terenius, J. Polak, S. R. Bloom, C. Sasek, R. Elde, and M. Goldstein (1983) Neuropeptide Y (NPY)- and FMRF-amide neuropeptide-like immunoreactivities in catecholamine neurons of the rat medulla oblongata. Acta Physiol. Scand. 117: 315-318.

Hunt, S. P., P. C. Emson, R. Gilbert, M. Goldstein, and J. Kimmel (1981) Presence of avian pancreatic polypeptide-like immunoreactivity in catecholamine and methionine enkephalin-containing neurons within the central nervous system. Neurosci. Lett. 21: 125-130.

Jacobowitz, D. M., and J. A. Olschowka (1982) Bovine pancreatic polypeptide-like immunoreactivity in brain and peripheral nervous system: Co-existence with catecholaminergic nerves. Peptides 3: 562590 .

Kimmel, J. R., L. J. Hayden, and H. G. Pollak (1975) Isolation and characterization of a new pancreatic polypeptide hormone. J. Biol. Chem. 250: 9369-9376.

Larsson, L. I., F. Sundler, and R. Håkanson (1976) Pancreatic polypeptide-a postulated new hormone: Identification of its cellular storage site by light- and electron microscopic immunocytochemistry. Diabetologica 12: 211-226.

Lin, T. -M., and R. E. Chance (1974) Candidate hormones of the gut: Bovine pancreatic polypeptide (BPP) and avian pancreatic polypeptide (APP). Gastroenterology 67: 737-738.

Lorén, I., J. Alumets, R. Håkanson, and F. Sundler (1979) Immunoreactive pancreatic polypeptide (PP) occurs in the central and peripheral nervous system: Preliminary immunocytochemical observations. Cell Tissue Res. 200: 179-186.

Lundberg, J. M., T. Hökfelt, A. Änggård, J. Kimmel, M. Goldstein, and K. Markey (1980) Co-existence of an avian pancreatic polypeptide (APP) immunoreactive substance and catecholamines in some peripheral and central neurons. Acta Physiol. Scand. 110: 107-109.

Lundberg, J. M., T. Hökfelt, A. Änggård, L. Terenius, R. Elde, K. Markey, and M. Goldstein (1982a) Organization principles in the peripheral sympathetic nervous system: Subdivisions by co-existing peptides (somatostatin-, avian pancreatic polypeptide- and vasoactive intestinal polypeptide-like immunoreactive materials). Proc. Natl. Acad. Sci. U. S. A. 79: 1303-1307.

Lundberg. J. M., K. Tatemoto, L. Terenius, P. M. Hellström, V. Mutt, T. Hökfelt, and B. Hamberger (1982b) Localization of peptide Y (PYY) in gastrointestinal endocrine cells and effects on intestinal blood flow and motility. Proc. Natl. Acad. Sci. U. S. A. 79: 44714475 .

Lundberg, J. M., L. 'I'erenius, 'T'. Hökfelt, C. -R. Martling, K. 'I'atemoto, V. Mutt, J. M. Polak, S. R. Bloom, and M. Goldstein (1982c) Neuropeptide Y (NPY)-like immunoreactivity in peripheral noradrenergic neurons and effects of NPY on sympathetic functions. Acta Physiol. Scand. 116: 477-480.

Olschowka, J. A., T. L. O'Donohue, and D. M. Jacobowitz (1981) The distribution of bovine pancreatic polypeptide-like immunoreactive neurons in rat brain. Peptides 2: 309-331.

Pease, P. C. (1962) Buffered formaldehyde as a killing agent and primary fixative for electron microscopy. Anat. Res. 142: 342 .

Price, D. A., and M. I. Greenberg (1977) Structure of a molluscan cardioexcicatory neuropeptide. Science 197: 670-671.

Sundler, F., E. Moghimzadeh, R. Håkanson, M. Ekelund, and P. Emson (1983) Neuropeptide $Y$-immunoreactive nerve fibers in the gut and pancreas. Intrinsic and extrinsic origin. Cell 'I'issue Res. 230: 487493.

Tatemoto, K. (1982a) Isolation and characterization of peptide YY (PYY), a candidate gut hormone that inhibits pancreatic exocrine secretion. Proc. Natl. Acad. Sci. U. S. A. 79: 2514-2518.

Tatemoto, K. (1982b) Neuropeptide Y: The complete amino acid sequence of the brain peptide. Proc. Natl. Acad. Sci. U. S. A. 79: 54855489 .

Tatemoto, K., M. Carlquist, and V. Mutt (1982) Neuropeptide Y-a novel brain peptide with structural similarities to peptide $\mathrm{YY}$ and pancreatic polypeptides. Nature (Lond). 269: 659-660.

Taylor, I. L., and C. R. Vaillant (1983) Pancreatic polypeptide-like materials in nerves and endocrine cells of the rat. Peptides 4: 245253. 